\title{
Predictive models for grazing distribution: A GIS approach
}

\author{
BRENT L. BROCK AND CLENTON E. OWENSBY
}

\begin{abstract}
The authors are research assistant, Div. of Biology, Kansas State University, Manhattan, Kans. 66506; and professor, Dept. of Agronomy, Kansas State University, Manhattan, Kans. 66506. This research was conducted in partial fulfillment of requirements for a Master of Science degree in Range Science for the senior author.
\end{abstract}

\begin{abstract}
Grazing distribution and forage use patterns are important influences on rangeland ecosystems. Spatial patterns of grazing by domestic cattle (Bos taurus) were observed over 2 consecutive years under 2 grazing systems, intensive-early stocking and season-long stocking. The purposes were to determine factors influencing observed patterns and develop predictive models for grazing distribution and forage removal. Field-collected data on grazing distribution were linked with associated geophysical properties of pastures utilizing a GIS. Separate models were developed to predict grazing distribution and forage utilization using a backward stepwise regression procedure. The forage utilization model was linked with grazing distribution by utilizing Tobit analysis. Nineteen independent variables were used to interpret the observed variation in grazing distribution. Comparison of predicted probability of grazing values from the model with the observed grazing distribution in a hold-out data set yielded a close fit $(\mathbf{R}=.99)$. Eighteen independent variables were included in the forage removal model. Comparison of predicted forage removal with observed values in a hold-out data set yielded a poor fit $(\mathbf{R}=.28)$. Lack of forage quality variables probably accounts for the poor performance of the forage removal model. Differences in the success of the $\mathbf{2}$ models support the hypothesis that grazing distribution and forage utilization operate at different spatial scales and parameters. The use of GIS holds promise as a technique for developing useful predictive models for range management.
\end{abstract}

Key Words: cattle, grazing patterns, modeling, utilization

A major objective in range management is achieving uniform grazing distribution (Holechek et al. 1989, Provenza 1991, Richards and Huntsinger 1994, Walker 1995). Several factors have been identified as important influences on grazing distribution. The most notable of these are slope and distance to water (Martin and Ward 1970, Cook 1966, Gillen et al. 1984, Mueggler 1965, Pinchak et al. 1991, Roath and Krueger 1982, Senft et al. 1983), but grazing distribution can be influenced by multiple fac-

Contribution no. 99-38-J from the Kansas Agricultural Experiment Station.

The authors thank Dr. George Milliken for assistance with statistical analysis We also thank Neal Adam, Lisa Auen, Michelle Keeler, and Kirk Horinek for data collection and technical support. Thanks also to Dr. John M. Briggs and the Konza Prairie LTER program for generous access to the KPRNA GIS Laboratory. Data for weather used in models was supported by the NSF Long Term Ecological Research Program at Konza Prairie Research Natural Area.

Manuscript accepted 24 April 1999.

\section{Resumen}

La distribución del apacentamiento y los patrones de uso del forraje son factores importantes en los ecosistemas de pastizal. Durante 2 años consecutivos se observaron los patrones espaciales de apacentamiento del ganado doméstico (Bos taurus) en dos sistemas de apacentamiento, apacentamiento intensivo temprano y apacentamiento continuo. Los objetivos del estudio fueron determinar los factores que influyen en los patrones observados y desarrollar modelos predictivos para la distribución del apacentamiento y la remoción de forraje. Datos de campo de la distribución del apacentamiento se vincularon mediante el uso de GIS con propiedades geofísicas asociadas a los potreros. Con el uso de técnicas de regresión se desarrollaron modelos separados para predecir la distribución del apacentamiento y la utilización del forraje. El modelo de utilización de forraje se vinculó con la distribución del apacentamiento mediante el análisis de "Tobit". Se utilizaron 19 variables independientes para interpretar la variación observada en la distribución del apacentamiento. La comparación de la probabilidad predicha de los valores de apacentamiento del modelo con la distribución del apacentamiento observada en un grupo de datos tuvo un buen ajuste $(R=.99)$. Se incluyeron 18 variables independientes en el modelo de remoción de forraje. La comparación de la remoción de forraje predicha con los valores observados en el juego de datos dio un ajuste pobre $(R=.28)$. La falta de variables de calidad de forraje probablemente contribuyó a la falta de ajuste del modelo de remoción de forraje. La diferencia en el éxito de los 2 modelos soporta la hipótesis que la distribución del apacentamiento y la utilización del forraje operan a diferentes parámetros y escales espaciales. El uso de GIS promete ser una técnica para desarrollar modelos predictivos útiles para el manejo de pastizales.

tors including: forage quantity or quality, distance to mineral supplement, proximity to fences, pasture size, abundance of weeds, and weather, (Bailey et al. 1989, Clary et al. 1978, Ehrenreich and Bjugstad 1966, Hart et al. 1991, Hein and Miller 1992, Owens et al. 1991, Senft et al. 1983, Smith and Owensby 1978). These factors are interrelated and influence grazing distribution in complex ways (Bailey et al. 1996).

Attempts to model grazing distribution have met with various degrees of success ( Cook 1966, Gillen et al. 1984, Pinchak et al. 1991, Senft et al. 1983, Wade et. al. 1998). Regardless, development of models to predict grazing distribution is relatively rare (Senft et al. 1983, Wade et. al. 1998). Difficulties in developing these models arise from the large number of cofactors that create 
a high degree of spatial and temporal heterogeneity across landscapes. The logistical difficulties of calculating and analyzing the many variables necessary to develop a useful model were once enormous. Additionally, a model is of little value, from a range management standpoint, if collecting the data necessary to parameterize the model is cumbersome or expensive. Recent advances in computer technology, particularly in the areas of geographic information systems (GIS), remote sensing and statistics, have significantly ameliorated these barriers. Large volumes of spatial data can now be assembled and manipulated with relative ease.

The objective of this study was to develop separate predictive models of grazing distribution and forage utilization based on pasture physical features using GIS. Additionally, an attempt was made to use only publicly available or easily obtainable data for model development.

\section{Methods}

Data were collected in 1993 and 1994 on the Rannells Flint Hills Prairie Preserve (RFHP), a 1,093 hectare tallgrass prairie located immediately south of Manhattan in the Flint Hills region of Kansas $\left(39^{\circ} 10^{\prime} \mathrm{N}\right.$, $\left.96^{\circ} 30^{\prime} \mathrm{W}\right)$. The climate is continental with an average of 178 frost-free days extending from 22 April to 17 October. Average total annual precipitation is $835 \mathrm{~mm}$, and the average monthly low temperature ranges from $-2.7^{\circ} \mathrm{C}$ in January to $26.6^{\circ} \mathrm{C}$ in July. The vegetation is predominantly tallgrass prairie dominated by big bluestem (Andropogon gerardii Vitman), little bluestem [Schizachyrium scoparium (Michx.) Nash], and Indiangrass [Sorghastrum nutans (L.) Nash]. Loamy upland [Benfield (fine, mixed, mesic Udic Argiustolls)-Florence (clayey-skeletal, montmorrillonitic, mesic Udic Arguistolls) complex] and limy upland [Clime (fine, mixed, mesic Udic Haplustolls)-Sogn (loamy, mixed, mesic Lithic Haplustolls) complex] range sites comprise most of RFHP with interspersions of clay upland [Dwight (fine, montmorillonitic, mesic Typic Natrustolls)-Irwin (fine, mixed, mesic Pachic Argiustolls)] and breaks (steep stony land) range sites. The RFHP is subjected to annual prescribed burning in late April, and the entire area is managed for cattle grazing.

Data were collected on 4 contiguous pastures of approximately 30 hectares each. All pastures were stocked with predominantly British $\mathrm{x}$ Zebu cross steers
(275 kg.). The turnout date for all pastures was approximately 10 May. Two pastures were seasonlong stocked, and the other 2 were intensive-early stocked (Fig. 1). Stocking rates were 1.6 hectare/steer for season-long stocked pastures and 0.8 hectare/steer for in ten sive - e a r ly stocked pastures. Cattle were removed on approximately 15 July and 1 October for intensive-early stocked and seasonlong stocked pastures, respectively.

Permanent line transects were marked at $18 \mathrm{~m}$ intervals across the entire width of each pasture. Data were recorded every 2 weeks at $10 \mathrm{~m}$ intervals along each transect using modified s t e p - p o i n t e r s (Owensby 1973).

Each sampling point was scored as grazed or ungrazed, and the canopy height was scored into 1 of 9 height categories using an index pole. Canopy height categories were: $0-5 \mathrm{~cm}, 5-10 \mathrm{~cm}, 10-20 \mathrm{~cm}$, $20-30 \mathrm{~cm}, 30-40 \mathrm{~cm}, 40-50 \mathrm{~cm}, 50-60 \mathrm{~cm}$, $60-70 \mathrm{~cm}$, and $70-80 \mathrm{~cm}$. Points located in areas lacking palatable forage (e.g. bare ground or impenetrable woody thickets) were scored as ungrazable and were excluded from data analysis because these points were considered outside the range of potential grazing sites. The effect of removing ungrazable points from analysis on the models was probably negligible because ungrazable patches were small (usually $<3 \mathrm{~m}$ diameter) and represented $<1 \%$ of total points surveyed. Approximately 1,800 points were recorded for each pasture per sampling date. That number varied depending upon the number of points needed to achieve complete pasture coverage. Logistical problems, abnormally high rainfall, and loss of data from failure of a data logger in 1993 limited the number of sampling dates to a single sampling date for the intensive-early stocked pastures. All data points were assigned map coordinates by georeferencing them to a $1: 12,000$ scale digital ortho images of the study area using ARC/INFO and Arcview (ESRI, Redlands, Calif.) GIS.

Percent forage utilized was calculated by comparing the canopy heights of each grazed point with an estimate of the ungrazed height for the point. All data points were grouped first by range site to account for soil, plant community, and topographical influences on canopy height. Range site boundaries were derived from 1:24,000 scale Soil Survey Geographic Database (SSURGO) data with hand-digitized and ground-truthed modifications. These data were subdivided further into $50 \mathrm{~m} \mathrm{x} 50 \mathrm{~m}$ cells to minimize the influence of spatial variability on plant heights. Estimates for ungrazed canopy height were obtained using the GIS by taking the mean of the canopy heights of all ungrazed points within the cell and range site where the grazed point was located. Forage removal was calculated for each grazed data point with the following equation:

$$
\mathrm{Fi}=\frac{(\hat{\mathrm{Ui}}-2.5 \mathrm{~cm})-\mathrm{gi}-2.5 \mathrm{~cm})}{\hat{\mathrm{U} i}-2.5 \mathrm{~cm}} * 100
$$


where $F_{\mathrm{i}}$ is the percent forage removed at the $i^{\text {th }}$ data point, $\hat{U} i$ is the estimated ungrazed canopy height at the $i^{\text {th }}$ data point, and $g_{i}$ is the grazed canopy ht of the ith data point. Under the assumption that cattle could not graze below a $2.5 \mathrm{~cm}$ vegetation height, $2.5 \mathrm{~cm}$ was subtracted from $g$ and $\hat{U}$.

Independent samples were taken in 1996 to determine the relationship between forage utilization based on canopy height and forage utilization estimates based on biomass. This was accomplished by systematically choosing 10 grazed patches to represent the full range of grazing intensities present. A $0.25 \mathrm{~m}^{2}$ quadrat of each grazed patch was clipped to a height of $2 \mathrm{~cm}$. Five ungrazed quadrats were selected randomly and clipped within $50 \mathrm{~m}$ of each grazed quadrat. Clipped samples were oven dried at $50^{\circ} \mathrm{C}$ for 48 hours and weighed to the nearest $0.01 \mathrm{~g}$. Forage removal was calculated for each grazed patch as;

$$
\mathrm{F}=\frac{\bar{u}-g}{\bar{u}} * 100
$$

where $\bar{u}$ is the mean biomass of ungrazed samples associated with each grazed quadrat, and $g$ is the biomass of the grazed quadrat. The data indicated a log linear relationship $(\mathrm{y}=65.812 \mathrm{Ln}(\mathrm{x})$ - 205.91, R2 $=.87, \mathrm{n}=10$, where $\mathrm{y}=$ utilization expressed as biomass and $\mathrm{x}=$ utilization based on canopy height).

Additional GIS layers were developed to assign attributes to the field-collected data. Slope, slope surface area, and aspect covers were obtained by calculating triangulated irregular networks (TIN) from 1:24,000 scale USGS Digital Elevation Models (DEM). Fence line boundaries were hand digitized from ortho images. Stock water and mineral feeder locations, as well as pond boundaries, were located using a hand-held Global Positioning System (GPS) unit. Shade boundaries were constructed by running a supervised classification on the digital ortho images and correcting for errors with hand digitizing. These map layers were overlaid with the field data to assign attributes to each data point.

Separate models were created to predict grazing distribution and forage removal by cattle. The models were linked following the model described by Tobin (1958) commonly referred to as Tobit analysis. The grazing distribution model was fit using Proc Genmod (SAS Institute Inc.1993), which fits a general linear model with logistic link function and binary distribution of the form:

$$
P=\frac{\mathrm{e}^{\mathrm{x}^{\prime} \beta}}{1+\mathrm{e}^{\mathrm{x}^{\prime} \beta}}
$$

where $P$ is the predicted probability of grazing, $x^{\prime}$ is a matrix of covariates or independent variables, and $B$ is a vector of unknown regression parameters.

All variables, as well as all possible interaction combinations, were used, and nonsignificant variables were removed iteratively until only significant $(\mathrm{p}<0.05)$ variables remained. Predicted values were calculated and mapped for each data point. These values represent the predicted probability of a given location being grazed.

Forage removal was modeled using the Lifereg procedure (SAS Institute Inc. 1996) and the classic Tobit model (Tobin 1958) which has the following form:

$$
y=\max \left(\mathrm{x}^{\prime} \beta+\varepsilon, 0\right)
$$

which is a regression model with left censoring, where $y$ is the vector of response variables, $\mathrm{x}^{\prime}$ is a matrix of covariates or independent variables, $\varepsilon$ is a vector of unknown regression parameters, and e is a vector of errors.

Significant variables determined in the grazing distribution model were used as explanatory variables. The model was defined further by left-censoring on the variable "grazing", so the forage removal model was fit using only the grazed data points. Nonsignificant $(p>0.05)$ were again removed iteratively until only significant terms remained in the model. The model was fit with a normal distribution, and predicted values were calculated using the following formulas adapted from Greene (1993):

$$
\text { pred }=\mathrm{x} \beta+\sigma \frac{\phi}{\Phi}
$$

where

$$
\phi=\frac{1}{\sqrt{2 \pi}} \mathrm{e}^{-\frac{1}{2}\left(\frac{x \beta}{\sigma}\right)^{2}}
$$

and

$$
\Phi=\int_{-\infty}^{x} \frac{1}{\sqrt{2 \pi}} e^{-\frac{1}{2}\left(\frac{x \beta}{\sigma}\right)^{2}} d x
$$

Significant interactions occurred between year and several variables in both models. The inclusion of year as an explanatory variable would have destroyed the predictive capabilities of the models, because separate models would be required for any year. We hypothesized that the observed differences in years were due to substantial differences in weather conditions. A new variable (P:E) was created to account for these differences. This is the ratio of total precipitation for the 2week period prior to the sampling date to the total pan water evaporation for the same period. This ratio was chosen because it incorporates the effects of temperature, humidity, and rainfall into a single index. Inclusion of this variable achieved the objective of causing all year interactions to drop out of the models.

Both models were tested by randomly withholding $20 \%$ of the data from the model fitting procedure. Calculating predicted values for this hold-out data set provided insights regarding the accuracy of the models. This was accomplished by regression analysis of predicted values for the hold-out data set plotted against the actual values. Spearman's rank correlation was used to test the forage removal model (SAS Institute Inc. 1996). To test the grazing distribution model, predicted probabilities were divided into 10 categories and plotted against the percentage of points within each prediction class that actually were grazed.

\section{Results}

Figures 2 and 3 show plots of actual and predicted distributions of grazing (Fig. 2) and forage removal (Fig. 3) for 3 sampling dates. These dates correspond to the beginning of the grazing season, seasonlong stocked mid-season/intensive-early stocked late-season, and season-long stocked late-season. Nineteen variables were significant for explaining the observed grazing distributions and 18 variables for explaining forage removal (Table 1). Grazing treatment had the largest effect on both models, with coefficients of 2.281 and 50.900 for grazing distribution and forage removal, respectively. No other variables exhibited dominant effects on the models (Appendix 1). The large number of significant variables with small associated coefficients demonstrates the complexity of the mechanisms regulating grazing distribution and forage removal.

The grazing distribution model was better at prediction than the forage removal model. A linear increase $(\mathrm{R}=.99)$ occurred in the proportion of observed grazed points with increases in predicted probability of grazing (Fig. 4). The scatter plot of observed versus predicted forage removal yields a very weak $(\mathrm{R}=.28)$ relationship between observed and expected values (Fig. 5). 

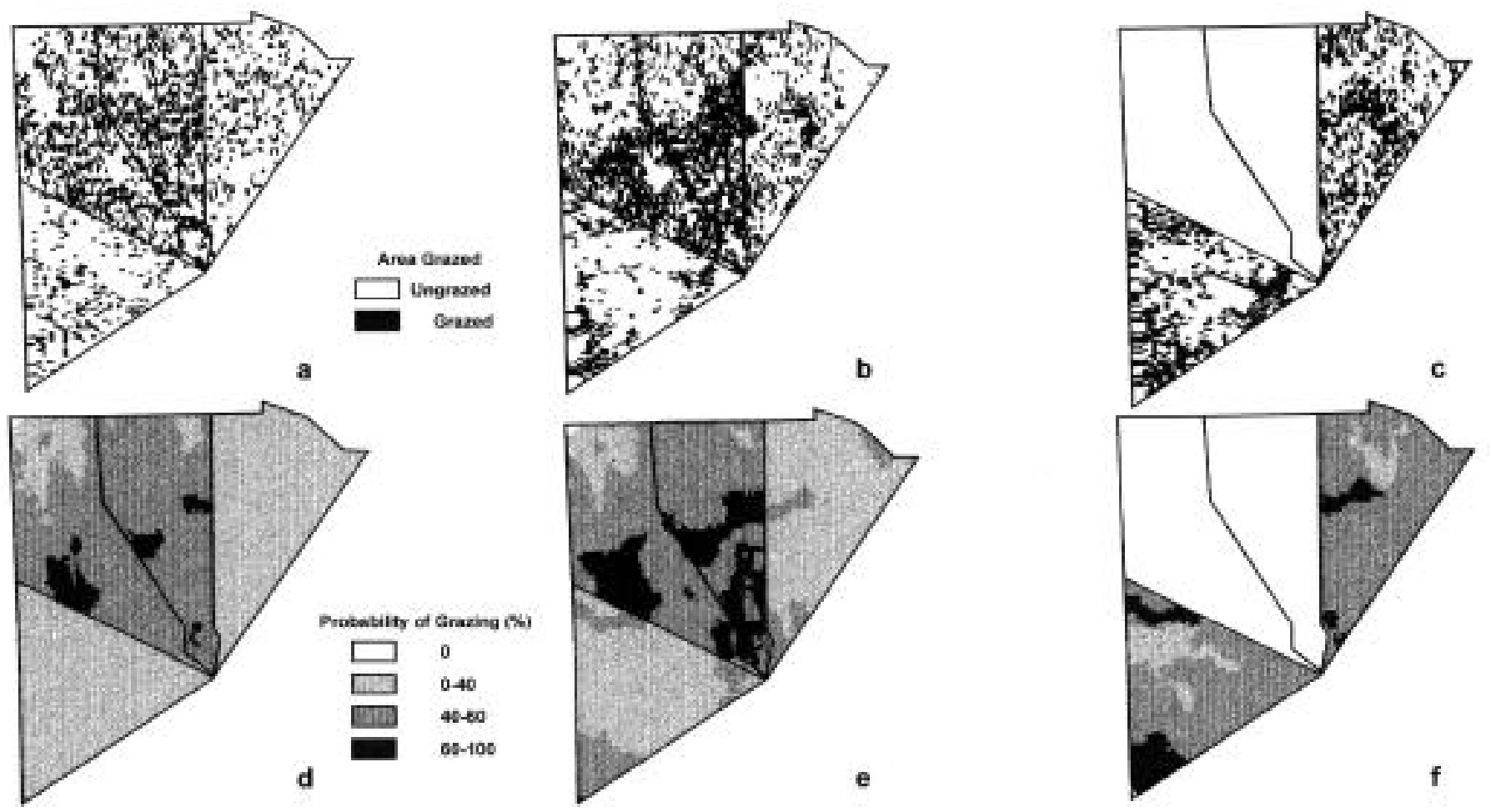

Fig. 2. Actual and predicted grazing distributions for 3 selected dates. a) actual distribution, 25 May, 1994. b) actual distribution, 20 July, 1994. c) actual distribution, 27 Sept., 1994. d) predicted distribution, 25 May, 1994. e) predicted distribution, 20 July, 1994. f) predicted distribution, 27 Sept., 1994.
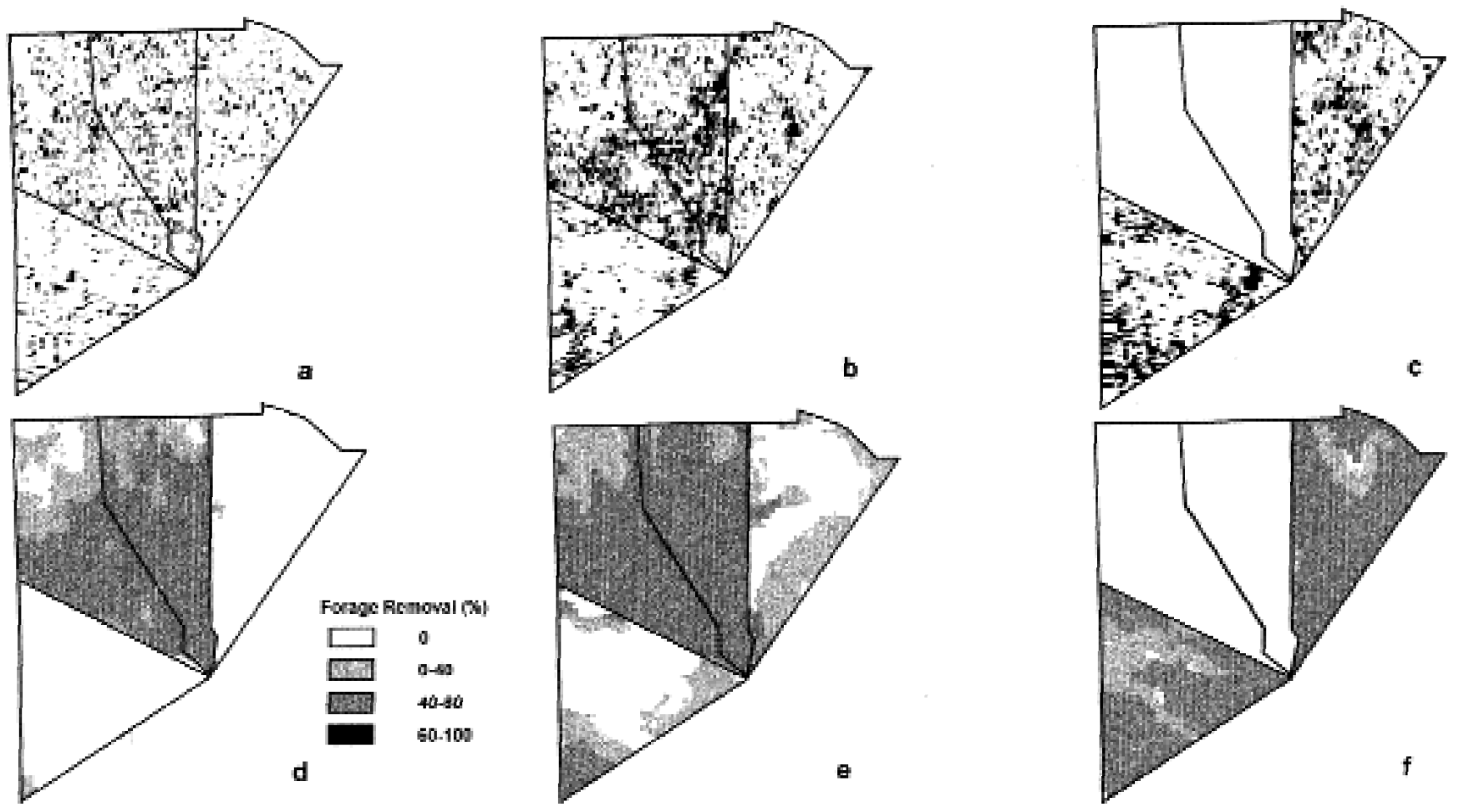

Fig. 3. Actual and predicted forage removals for 3 selected dates. a) actual removal, 25 May, 1994. b) actual removal, 20 July, 1994. c) actual removal, 27 Sept., 1994. d) predicted removal, 25 May, 1994. e) predicted removal, 20 July, 1994. f) predicted removal, 27 Sept., 1994. 
Table 1. Significant $(P<0.05)$ terms in forage resource use models.

\begin{tabular}{|c|c|c|}
\hline Source & Grazing Distribution & Forage Removal \\
\hline $\mathrm{TRT}^{1}$ & $*$ & $*$ \\
\hline Date $^{2}$ x Slope ${ }^{3}$ & $*$ & $*$ \\
\hline Date x SAREA ${ }^{4}$ & $*$ & $*$ \\
\hline Date $x$ Aspect $^{5}$ x TRT & $*$ & \\
\hline Date $x$ Range Site $^{6}$ x TRT & * & $*$ \\
\hline Date $\mathrm{x}$ Distance to $\mathrm{H} 2 \mathrm{O} \times \mathrm{TRT}$ & $*$ & $*$ \\
\hline Date $\mathrm{x}$ Distance to Mineral $\mathrm{x}$ TRT & $*$ & $*$ \\
\hline Date $\mathrm{x}$ Distance to Shade $\mathrm{x}$ TRT & $*$ & $*$ \\
\hline Date $\mathrm{x}$ Distance to Range Site Boundary $\mathrm{x}$ TRT & $*$ & $*$ \\
\hline Date $\mathrm{x}$ Distance to Fence Corner ${ }^{7} \mathrm{x}$ TRT & $*$ & $*$ \\
\hline SAREA x P:E & $*$ & $*$ \\
\hline Distance to Range Site Boundary x P:E & $*$ & $*$ \\
\hline Aspect x P:E x TRT & $*$ & $*$ \\
\hline Slope x P:E x TRT & $*$ & $*$ \\
\hline P:E x Range Site x TRT & $*$ & $*$ \\
\hline Distance to $\mathrm{H} 2 \mathrm{O} \times \mathrm{P}: \mathrm{E} \times \mathrm{TRT}$ & $*$ & $*$ \\
\hline Distance to Mineral x P:E x TRT & $*$ & $*$ \\
\hline Distance to Shade x P:E x TRT & $*$ & $*$ \\
\hline P:E x Distance to Fence $x$ TRT & $*$ & $*$ \\
\hline \multicolumn{3}{|c|}{$\begin{array}{l}\text { *Significant at } \mathrm{P}<0.05 \\
{ }^{1} \text { TRT=Grazing Treatment; intensive early stocked (IES), or season-long stocked (SLS). } \\
{ }^{2} \text { DATE=Calendar day of year. } \\
{ }^{3} \text { SLOPE=Percent slope. } \\
{ }^{4} \text { SAREA=Surface area of a plane with equal slope } \\
{ }^{5} \text { Aspect=Slope aspect in degrees, assigned to } 8 \text { equal classes from } 0^{\circ} \text { (North) clockwise to } 360^{\circ} \text {. } \\
6 \text { The study area contained } 5 \text { range sites: Breaks (Steep Stoney land), Clay Upland, Limey Upland, Loamy Upland, and } \\
\text { Loamy Lowland. }\end{array}$} \\
\hline
\end{tabular}

\section{Discussion}

\section{Influence of Scale on Models}

Mechanisms that affect large herbivore foraging operate over a range of spatial and temporal scales (Bailey et al. 1996, Senft et al. 1987, Senft 1989). General grazing patterns are landscape-level processes and are constrained by geophysical, or abiotic, features. Within the constraints of the abiotic landscape, resource utilization patterns are dictated by smaller-scale foraging decision processes. These processes are influenced by biotic factors at the plant community level or lower. Chief among these factors are forage abundance, quality, and palatability (Bailey et al. 1989, Clary et al. 1978, Owens et al. 1991, Senft et al. 1985, Senft et al. 1987, Senft 1989). In light of this, it is not surprising that the model presented here for grazing distribution succeeded, whereas the model for forage removal failed in predicting patterns of grazing resource use. The models developed relied almost entirely on abiotic variables, which are reasonably good estimators of landscape-level grazing patterns. However, the degree of forage usage within grazed sites is determined by characteristics of the plant community at relatively small scales. Descriptive variables for these characteris-

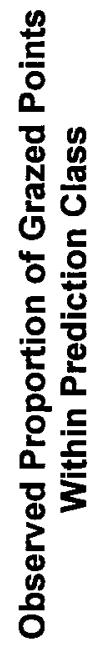

and is not a measure of the actual community present.

Although the models were unable to accurately predict forage removal, the concept of linking the models is valid. Herbivore forage removal does not operate independently of grazing distribution but, rather, is constrained by grazing distribution patterns. A direct relationship will always exist between forage utilization and the probability of grazing. Other models for forage preference have been developed, but they should be used in the context of larger scale processes that guide herbivore habitat selection (Loehle and Rittenhouse 1982, Senft 1989). The influence of landscape-scale abiotic features on smaller scale foraging decisions is accounted for by linking the models.

\section{Model Limitations}

To be of value to range managers, models of forage resource utilization should be accurate over a wide range of conditions. Previous grazing models have been limited by being site specific (Bailey et al. 1996, Senft et al. 1985, Senft 1989). In their current form, the models presented here also suffer this limitation. Several limitations were imposed by the experimental design and the data from which descriptive variables were derived. The models were derived from data collected on relatively small, equally-sized pastures. Pasture size can interact with other factors and influence grazing patterns (Hart et al. 1993), this term probably would need to be added before the model could be applied to a variety of pastures.

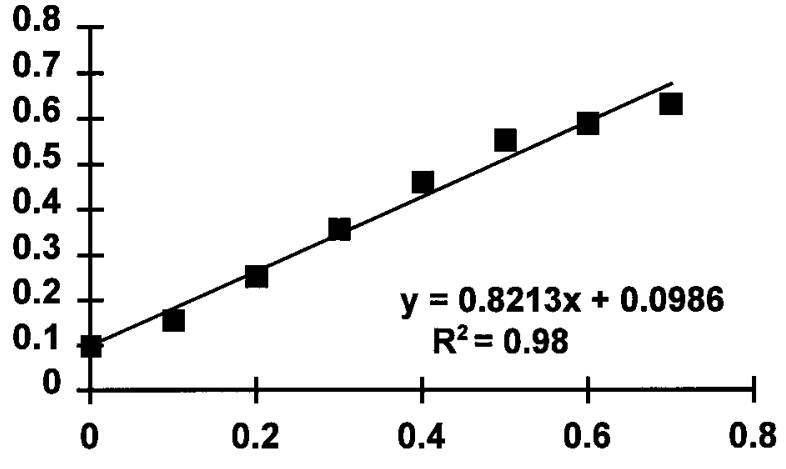

\section{Predicted Probability of Grazing}

Fig. 4. Observed proportion of grazed points within a prediction class vs. predicted probability of a point being grazed. Regression was obtained from data that were withheld from the model-fitting process. 


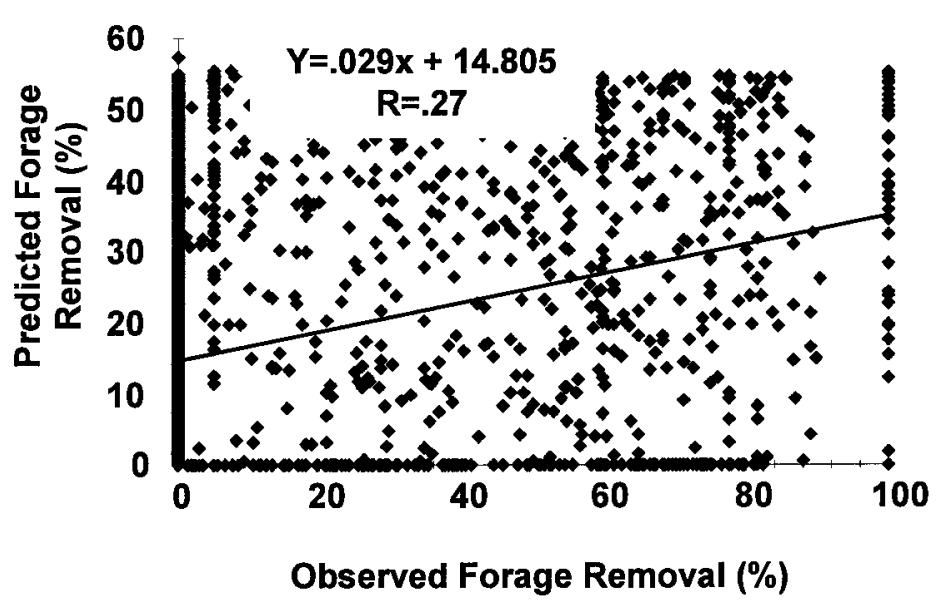

Fig. 5. Observed forage removal vs. predicted from model. The plot has been reduced to 3,000 randomly chosen points for clarity, but the regression equation is calculated from the entire hold-out data set.

Additionally, all 4 pastures were burned, which also could limit the use of these models on unburned pastures. Grazers are attracted to burned areas (Lewis 1953), and cattle will concentrate grazing on burned patches (Wright 1974). Conversely, burning can remove the attractive influence of previously grazed patches to grazers (Coppock and Detling 1986, Hobbs et al. 1991). Application of our models to unburned or partially burned pastures may require additional terms to account for the influence of burning on grazing distribution. Such data are readily available in the form of remotely sensed images.

The use of classification variables limits the applicability of models by requiring new coefficients to be determined for each new class encountered. The current models include 2 classification variables: grazing treatment and range site. An alternative to determining separate coefficients for each possible class is to substitute continuous variables that explain effects the classification variables are having on the models. Grazing treatment actually may be a continuous variable, which could be expressed as AU/unit area, because these treatments represent $1 \mathrm{x}$ versus $2 \mathrm{x}$ of normal stocking rates. However, with only 2 classes, fitting a regression line with any degree of confidence is impossible. Therefore, it is safer to leave grazing treatment as a classification variable until further data on a variety of stocking rates are obtained. Similarly, the influence of range site on these models may be due to differences in forage abundance and quality, which might be good candidates for substitution.
The usefulness of models of forage resource utilization to range managers is enhanced if they are easily derived. Previous models have been limited by reliance on field-collected data as descriptive parameters. Such data often are timeconsuming and expensive to obtain. Models that rely on readily available public data should enjoy wider use among range professionals. In this respect, the models presented are superior, because they rely almost exclusively on publicly available digital data. The only additional data required are water and mineral locations and pasture fence boundaries. However, limiting model parameters to publicly available data can result in reduction in model performance, as is demonstrated by the relative performance of our 2 models. Although the public domain is relatively rich in digital data describing geophysical features, useful information about plant communities is lacking at small scales/high resolution. Although several indices for plant community structure can be calculated from remotely sensed data, such data generally are too coarse in spatial and/or spectral resolution to accurately model small-scale herbivore foraging processes. However, as the trend toward remotely sensed data with higher spectral and spatial resolutions continues, this situation is likely to improve.

\section{Management implications}

Easily derived predictive models for forage resource utilization would be powerful tools for range resource professionals. Within the limitations discussed, the grazing distribution model presented here is reasonably accurate in predicting land- scape-level grazing patterns. Such information is useful to range professionals because most range management problems occur at these larger scales (Bailey et al. 1996). Our model has advantages in relying on existing and readily available predictive data and has the potential, with further development, to be applied over a wide area and combination of pasture conditions.

Perhaps the greatest advantage of this model is incorporation into a GIS. This allows for the automation of model simulations and the production of high quality maps of model predictions. With these tools, a range professional could easily explore the outcome of a variety of management possibilities before committing resources to a particular plan.

\section{Literature Cited}

Bailey, D.W., L.R. Rittenhouse, R.H. Hart, D.M. Swift, and R.W. Richards. 1989. Association of relative food availabilities and locations by cattle. J. Range Manage. 42:480-482.

Bailey, D.W., J.E. Gross, E.A. Laca, L.R. Rittenhouse, M.B. Coughenour, D.M. Swift, and P.L. Sims. 1996. Invited synthesis paper: Mechanisms that result in large herbivore grazing distribution patterns. J. Range Manage. 49:386-400.

Clary, W.P., P.F. Ffolliott, and F.R. Larson. 1978. Factors affecting forage consumption by cattle in Arizona ponderosa pine forests. J. Range Manage. 31:9-10.

Cook, C.W. 1966. Factors affecting utilization of mountain slopes by cattle. J. Range Manage. 19:200-204.

Coppock, D.L. and J.K. Detling. 1986. Alteration of bison and black-tailed prairie dog grazing interaction by prescribed burning. J. Wildl. Manage. 50:452-455.

Ehrenreich, J.H. and A.J. Bjugstad. 1966. Cattle grazing time is related to temperature and humidity. J. Range Manage. 19:141-142.

Gillen, R.L., W.C. Krueger, and R.F. Miller. 1984. Cattle distribution on mountain rangeland in northeastern Oregon. J. Range Manage. 37:549-553.

Greene, W.H. 1993. Econometric Analysis, $2^{\text {nd }}$ ed. Macmillan Publishing Company, New York.

Hart, R.H., J. Bissio, M.J. Samuel, and J.W. Waggoner, Jr. 1993. Grazing systems, pasture size, and cattle grazing behavior, distribution and gains. J. Range Manage. 46:81-87.

Hart, R.H., K.W. Hepworth, M.A. Smith, and J.W. Waggoner, Jr. 1991. Cattle grazing behavior on a foothill elk winter range in southeastern Wyoming. J. Range Manage. 44:262-266.

Hein, D.G. and S.D. Miller. 1992. Influence of leafy spurge on forage utilization by cattle. J. Range Manage. 45:405-407. 
Hobbs, N.T., D.S. Schimel, C.E. Owensby, and D.S. Ojima. 1991. Fire and grazing in the tallgrass prairie: contingent effects on nitrogen budgets. Ecol. 72:1374-1382.

Holechek, J.L., R.D. Peiper, and C.H. Gerbe. 1989. Range management principles and practices. Prentice Hall, Englewood Cliffs, N.J.

Lewis, M. (Bernard DeVoto, ed.) 1953. Original journals of the Lewis and Clark expedition. Houghton Mifflin, Boston, Mass.

Loehle, C. and L.R. Rittenhouse. 1982. An analysis of forage preference indices. J. Range Manage. 35:316-319.

Martin S.C. and D.E. Ward. 1970. Rotating access to water to improve semidesert cattle range near water. J. Range Manage. 23:22-26.

Mueggler, W.F. 1965. Cattle distribution on steep slopes. J. Range Manage. 18:255-257.

Owensby, C.E. 1973. Modified step-point system for botanical composition and basal cover estimates. J. Range Manage. 26:302-303.

Owens, M.K., K.L. Launchbaugh, and J.W. Holloway. 1991. Pasture characteristics affecting spatial distribution of utilization by cattle in mixed brush communities. J. Range Manage. 44:118-123.
Pinchak, W.E., M.A. Smith, R.H. Hart, and J.W. Waggoner, Jr. 1991. Beef cattle distribution patterns on foothill range. J. Range Manage. 44:267-275.

Provenza, F.D. 1991. Viewpoint: range science and range management are complimentary but distinct endeavors. J. Range Manage. 44:181-183.

Richards, R.T. and L. Huntsinger. 1994. Variation in BLM employee attitudes toward environmental conditions on rangeland. J. Range Manage. 47:365-368.

Roath, L.R. and W.C. Krueger. 1982. Cattle grazing and behavior on a forested range. $\mathrm{J}$. Range Manage. 35:332-338.

SAS Institute Inc. 1996. Procedures Guide. Statistical Analysis System, Inc., Cary,N.C.

SAS Institute Inc. 1993. SAS Technical Report P-243: the Genmod Procedure. Statistical Analysis System, Inc., Cary,N.C.

Senft., R.L. 1989. Hierarchical foraging models: effects of stocking and landscape composition on simulated resource use by cattle. Ecol. Modeling 46:283-303.

Senft. R.L., L.R. Rittenhouse, and R.G. Woodmansee. 1983. The use of regression models to predict spatial patterns of cattle behavior. J. Range Manage. 36:553-557.
Senft, R.L., L.R. Rittenhouse, and R.G. Woodmansee. 1985. Factors influencing patterns of cattle grazing behavior on shortgrass steppe. J. Range Manage. 38:82-87.

Senft, R.L., M.B. Coughenour, D.W. Bailey, L.R. Rittenhouse, O.E. Sala, and D.M. Swift. 1987. Large herbivore foraging and ecological hierarchies. Bioscience 37:789799

Smith, E.F. and C.E. Owensby. 1978. Intensive-early stocking and season-long stocking of Kansas Flint Hills range. J. Range Manage. 31:14-17.

Tobin, J. 1958. Estimation of relationships for limited dependent variables. Econometrica 26:24-36.

Wade, T.W., B.W. Schultz, J.D. Wickham, and D.F. Bradford. 1998. Modeling the potential spatial distribution of beef cattle grazing using a Geographic Information System. J. Arid Environ. 38:325-334.

Walker, J.W. 1995. Viewpoint: grazing management and research now and in the next millennium. J. Range Manage. 48:350-357.

Wright, H.A. 1974. Range burning. J. Range Manage. 27:5-11.

Appendix 1. Coefficients of significant model terms.

\begin{tabular}{|c|c|c|c|c|}
\hline Variable & Level 1 & Level 2 & $\begin{array}{l}\text { Coefficiant } \\
\text { (Grazing) }^{1}\end{array}$ & $\begin{array}{l}\text { Coefficiant } \\
\text { (Forage) }^{2}\end{array}$ \\
\hline TRT & IES & & $2.281 \mathrm{E}+00$ & $5.090 \mathrm{E}+01$ \\
\hline$P: E^{3} \times$ Range Site $^{4} \times$ TRT $^{5}$ & LL & SLS & $3.350 \mathrm{E}-02$ & \\
\hline P:E x Range Site x TRT & $\mathrm{LiU}$ & SLS & $3.130 \mathrm{E}-02$ & $9.770 \mathrm{E}-01$ \\
\hline P:E x Range Site x TRT & LU & SLS & $2.766 \mathrm{E}-02$ & $1.040 \mathrm{E}+00$ \\
\hline Date $^{6} \times$ Range Site $x$ TRT & LL & IES & $1.724 \mathrm{E}-02$ & 7.330E-01 \\
\hline Date x Range Site x TRT & $\mathrm{LiU}$ & IES & $1.512 \mathrm{E}-02$ & $6.803 \mathrm{E}-01$ \\
\hline Date $x$ Range Site $x$ TRT & $\mathrm{CU}$ & SLS & $1.417 \mathrm{E}-02$ & 5.004E-01 \\
\hline Date $x$ Range Site x TRT & $\mathrm{CU}$ & IES & $1.387 \mathrm{E}-02$ & $6.370 \mathrm{E}-01$ \\
\hline Date $x$ Range Site $x$ TRT & $\mathrm{Br}$ & SLS & $1.275 \mathrm{E}-02$ & $4.506 \mathrm{E}-01$ \\
\hline Date x Range Site x TRT & LU & IES & $1.236 \mathrm{E}-02$ & $5.840 \mathrm{E}-01$ \\
\hline Date $x$ Range Site $x$ TRT & $\mathrm{LiU}$ & SLS & $1.146 \mathrm{E}-02$ & $4.230 \mathrm{E}-01$ \\
\hline Date $x$ Range Site $x$ TRT & LL & SLS & $1.143 \mathrm{E}-02$ & $4.320 \mathrm{E}-01$ \\
\hline Date $x$ Range Site $x$ TRT & $\mathrm{Br}$ & IES & $1.034 \mathrm{E}-02$ & $4.956 \mathrm{E}-01$ \\
\hline P:E x Range Site x TRT & $\mathrm{Br}$ & SLS & $1.031 \mathrm{E}-02$ & $4.020 \mathrm{E}-01$ \\
\hline Date $x$ Range Site $x$ TRT & LU & SLS & $9.448 \mathrm{E}-03$ & $3.310 \mathrm{E}-01$ \\
\hline Slope $^{7}$ x P:E x TRT & IES & & $4.511 \mathrm{E}-04$ & $1.310 \mathrm{E}-02$ \\
\hline Dist. H2O x P:E x TRT & IES & & $1.889 \mathrm{E}-04$ & $6.586 \mathrm{E}-03$ \\
\hline Dist. Mineral x P:E x TRT & IES & & $5.598 \mathrm{E}-05$ & $1.636 \mathrm{E}-03$ \\
\hline Date x Dist. Shade x TRT & IES & & $4.093 \mathrm{E}-05$ & $1.273 \mathrm{E}-03$ \\
\hline Aspect $^{8} \times$ P:E x TRT & SLS & & $3.784 \mathrm{E}-05$ & $1.101 \mathrm{E}-03$ \\
\hline Aspect x P:E x TRT & IES & & $2.665 \mathrm{E}-05$ & \\
\hline Date x Dist. Range Site Bound. x TRT & SLS & & $1.175 \mathrm{E}-05$ & $5.037 \mathrm{E}-04$ \\
\hline Date $\mathrm{x}$ Dist. Shade $\mathrm{x}$ TRT & SLS & & $9.757 \mathrm{E}-06$ & $3.230 \mathrm{E}-04$ \\
\hline Date $x$ Dist. H2O x TRT & SLS & & $9.164 \mathrm{E}-06$ & $1.164 \mathrm{E}-03$ \\
\hline Date $\mathrm{x}$ Dist. Mineral $\mathrm{x}$ TRT & SLS & & $5.165 \mathrm{E}-06$ & $1.770 \mathrm{E}-04$ \\
\hline Dist. Shade x P:E x TRT & SLS & & $2.439 \mathrm{E}-06$ & \\
\hline Date $\mathrm{x}$ Dist. Corner ${ }^{9} \mathrm{x}$ TRT & IES & & $2.315 \mathrm{E}-06$ & $3.694 \mathrm{E}-05$ \\
\hline Date $x$ SAREA ${ }^{10}$ & & & $1.354 \mathrm{E}-07$ & $5.610 \mathrm{E}-06$ \\
\hline TRT & SLS & & $0.000 \mathrm{E}+00$ & $0.000 \mathrm{E}+00$ \\
\hline Date $\mathrm{x}$ Aspect $\mathrm{x}$ TRT & SLS & & $-2.310 \mathrm{E}-07$ & \\
\hline SAREA x P:E & & & $-1.077 \mathrm{E}-06$ & $-4.400 \mathrm{E}-05$ \\
\hline Dist. Mineral x P:E x TRT & SLS & & $-2.259 \mathrm{E}-06$ & \\
\hline Date $\mathrm{x}$ Aspect $\mathrm{x}$ TRT & IES & & $-2.665 \mathrm{E}-06$ & \\
\hline
\end{tabular}


Appendix 1. Continued.

\begin{tabular}{|c|c|c|c|c|}
\hline Variable & Level 1 & Level 2 & $\begin{array}{l}\text { Coefficiant } \\
\text { (Grazing) }^{1}\end{array}$ & $\begin{array}{l}\text { Coefficiant } \\
{\text { (Forage })^{2}}^{2}\end{array}$ \\
\hline Date x Dist. Corner x TRT & SLS & & $-2.786 \mathrm{E}-06$ & $-1.200 \mathrm{E}-04$ \\
\hline Date $x$ Dist. Range Site Bound. x TRT & IES & & $-6.837 \mathrm{E}-06$ & $3.176 \mathrm{E}-04$ \\
\hline Date x Dist. H2O x TRT & IES & & $-2.087 \mathrm{E}-05$ & $-7.297 \mathrm{E}-04$ \\
\hline P:E x Dist. FENCE x TRT & IES & & $-3.400 \mathrm{E}-05$ & $-1.880 \mathrm{E}-03$ \\
\hline Date x Slope & & & $-4.188 \mathrm{E}-05$ & $-1.190 \mathrm{E}-03$ \\
\hline P:E x Dist. FENCE x TRT & SLS & & $-1.817 \mathrm{E}-04$ & $-6.390 \mathrm{E}-03$ \\
\hline Dist. Shade x P:E x TRT & IES & & $-1.829 \mathrm{E}-04$ & $-5.401 \mathrm{E}-03$ \\
\hline Slope x P:E x TRT & SLS & & $-9.121 \mathrm{E}-04$ & $-3.480 \mathrm{E}-02$ \\
\hline P:E x Range Site x TRT & $\mathrm{CU}$ & SLS & $-1.236 \mathrm{E}-03$ & \\
\hline P:E x Range Site x TRT & $\mathrm{Br}$ & IES & $-6.224 \mathrm{E}-02$ & $-2.020 \mathrm{E}+00$ \\
\hline P:E x Range Site x TRT & $\mathrm{LiU}$ & IES & $-6.703 \mathrm{E}-02$ & $-2.290 \mathrm{E}+00$ \\
\hline
\end{tabular}

${ }^{\mathrm{T}}$ Coefficients for grazing distribution model.

${ }_{3}^{2}$ Coefficients for forage removal model.

${ }_{4}^{3}$ Ratio of total precipitation to total pan water evaporation for 2 week interval prior to sampling date.

${ }^{4}$ The study area contained 5 range sites: Breaks (Steep Stoney land), Clay Upland, Limey Upland, Loamy Upland, and Loamy Lowland.

${ }^{5}$ TRT=Grazing Treatment; intensive-early stocked (IES), or season-long stocked (SLS).

${ }_{7}^{6} \mathrm{DATE}=$ Calender day of year.

Slope=Percent slope.

${ }^{8}$ Aspect $=$ Slope aspect in degrees, assigned to 8 equal classes from $0^{\circ}$ (North) clockwise to $360^{\circ}$.

${ }^{9}$ Fence corners were defined by 2 fences connecting at ${ }^{3} 90^{\circ}$

${ }^{10}$ SAREA=Surface area of a plane with equal slope. 